\title{
Örgütsel Prestijin Örgütsel Özdeşleşme Düzeyine Etkisi: Sağlık İșletmelerinde Bir Uygulama
}

\author{
The Effect of Organizational Prestige on Organizational Identification Level: An Application in Health Care \\ Organizations
}

\author{
Yeşim YILMAZ SAYGU ${ }^{1}$, Aydan YÜCELER ${ }^{2}$
}

\begin{abstract}
ÖZ
Örgütsel prestij, hem örgüt çalışanlarının hem de müşterilerin üzerinde önemle durduğu konulardan biridir. Bunun en önemli nedenlerinden biri bireyin çalışmakta olduğu örgütü hakkında dış dünyanın düşüncelerine önem vermesidir. Örgütsel prestij çalışanın örgüte bakış açısını etkileyecek bu durumda çalışanın örgüt içindeki davranışlarının şekillenmesinde önemli bir etken olacaktır. Örgütsel özdeşleşme de bu davranışlardan bir tanesidir. Kurum ile çalışanın amaçlarının uyumlaştırılması ve bağlantı duygusunun sağlanması örgütsel özdeşleşmeyi tanımlamaktadır. Bu araştırma örgütsel prestijin örgütsel özdeşleşme üzerinde etkisini belirlemek amacıyla sağlık çalışanlarına uygulanmıştır.

Araştırmanın örneklemini Konya ilinde 5 özel hastanede görev yapan 283 sağlı çalışanı oluşturmaktadır. Verilerin toplanmasında kişisel bilgi formu, Örgütsel Prestij Ölçeği ve Örgütsel Özdeşleşme Ölçeği kullanılmıştır. Verilerin istatistiksel analizinde Pearson korelasyon analizi, tek yönlü varyans analizi, bağımsız iki örneklem $\mathrm{t}$ testi, ve doğrusal regresyon analizinden faydalanılmıştır. Analizlerde sonuçlar \%95'lik güven aralığında, 0,05 $(\mathrm{p}<0,05)$ anlamlılık düzeyinde değerlendirilmiştir. Bu çalışmada Örgütsel Prestij ve Örgütsel Özdeşleşme Ölçeklerinin Cronbach Alfa değerleri sirasıyla 0,627 ve 0,917 ; ölçek ortalamaları 3,35 ve 3,55 bulunmuştur. Sağlık çalışanlarının sadece meslek gruplarına göre örgütsel prestij ile örgütsel özdeşleşme düzeylerinde istatistiksel olarak anlamlı bir farklılık ve orta düzeyde anlamlı bir ilişki bulunmuştur.
\end{abstract}

Anahtar Kelimeler: Özdeşleşme, Örgütsel Özdeşleşme, Prestij, Örgütsel Prestij, Sağlık Çalışanları.

\begin{abstract}
Organizational prestige is one of the issues that both organization employees and customers emphasize. One of the most important reasons for this is that the individual cares about the thoughts of the outside world about the organization in which he works. Organizational prestige will affect the employee's perspective on the organization, and in this case, it will be an important factor in shaping the employee's behavior within the organization. Organizational identification is one of these behaviors. The harmonization of the objectives of the institution and the employee and the sense of connection define organizational identification. This research was applied to healthcare professionals in order to determine the effect of organizational prestige on organizational identification.
\end{abstract}

The sample of the study consists of 283 health workers working in 5 private hospitals in Konya province. The data were collected using the personal information form, the Perceived Organizational Prestige Scale and the Organizational Identification Scale. In the statistical analysis of the data, we performed independent samples $t$ test, one way ANOVA, Pearson correlation analysis and regression analysis at $95 \%$ confidence interval and significance level of 0.05 ( $\mathrm{p}<0.05$ ). In this study, the Cronbach's alpha values of the organizational prestige and organizational identification scales were 0.627 and 0.917 , and the mean of the scale was 3.35 and 3.55 , respectively. There was only a significant difference both organizational prestige and organizational identification levels according to occupational groups of healthcare workers. A moderate positive correlation between these two scales was found.

Keywords: Identification, Organizational Identification, Prestige, Organizational Prestige, Health Workers.

\footnotetext{
* Bu çalışma, Dr. Öğr. Üyesi Aydan Yüceler danışmanlı̆̆ında Yeşim YILMAZ SAYGU tarafindan Necmettin Erbakan Üniversitesi Sağlık Bilimleri Enstitüsü Sağlı Yönetimi A.D. 'nda hazırlanan aynı başlıklı tezden üretilmiştir.
${ }^{1}$ Bilim Uzmanı, Sağlık Yönetimi, Necmettin Erbakan Üniversitesi, Sağlık Bilimleri Enstitüsü Sağlık Yönetimi AD., yysmylmz@gmail.com, ORCID: 0000-0003-0501-2118
${ }^{2}$ Dr. Öğr. Üyesi, Sağlık Hizmetleri Yönetimi, Necmettin Erbakan Üniversitesi Sağlık Bilimleri Fakültesi Sağlık Yönetimi Bölümü, aydanyuceler@hotmail.com, ORCID: 0000- 0002-4322-4528




\section{GİRIŞ}

Günümüz dünyasında prestij kavramı pek çok alanda olduğu gibi örgütler açısından da önemli hale gelen kavramlardan biridir. Örgütler elde ettikleri prestijle hem müșterilerin kendi ürünlerini tercih etmesini sağlama hem de nitelikli personeli örgüte çekerek rekabet üstünlüğü sağlama noktasında büyük bir avantaj sağlayacaktır. Ayrıca örgütsel prestij çalışanların örgütle özdeşleşmesi noktasında katkı sağlayacaktır. $\mathrm{Bu}$ da günümüz işletmelerinin en büyük sorunlarından biri olan çalışanların örgütsel amaçlar doğrultusunda yönlendirilmesi, bu doğrultuda yüksek performans göstermeleri ve dolayısıyla örgütü sahiplenmelerinde destek olacaktır.

Dinamik ve karmaşık bir yapıya sahip olan sağlık işletmeleri için de prestij ve özdeşleşme kavramları büyük önem taşımaktadır. Sağlık kurumları hem kendi çalışanlarıyla hem de hastalarla sürekli etkileşim halindedir. $\mathrm{Bu}$ etkileşimin verimli şekilde uzun süreli devam edebilmesinde hastaların sadakati ve çalışanların kurumla olan uyumu önemli rol oynamaktadır. İş göreniyle uyum sağlayan örgütlerde çalışan kişiler sadece maaş alan bireyler değil aynı zamanda örgütü ailesi gibi görüp benimseyen kişilerdir. $\mathrm{Bu}$ bağlamda çalışılan yer ile çalışanların benliklerini bir bütün haline getirmek ve çalışanların içinde bulundukları örgütün üyesi oldukları için gurur duymalarını sağlamak günümüz sağlık işletmeleri için son derece önemli hale gelmiştir. ${ }^{1} \mathrm{Bu}$ bağlamda araştırma örgütsel prestijin sağlık çalışanlarının örgütsel özdeşleşmesindeki etkisini ortaya koymayı amaçlamıştır. Sağlık işletmelerinde örgütsel özdeşleşme ve örgütsel prestij arasındaki ilişkinin ölçülmesi çalışanlarının örgüt hakkındaki tutum ve görüşlerini öngörebilmek açısından önem arz etmektedir.

Örgütsel prestij kurum içinde çalışanların kurum dışındakilerin değerlendirmesini baz alarak oluşturdukları algı şeklinde tanımlanmaktadır. ${ }^{2}$ Dutton ve Dukerich'e göre kavram, kurumun sosyal değerlendirmesiyle ilgili olarak daha çok bilgi edinilmesine yardımcı olur. ${ }^{3}$ Çünkü örgütsel prestij kurumlar için bir nevi ayna görevi görmektedir. $\mathrm{Bu}$ sayede çalışanlar kurumlarının dışarıdan nasıl göründüğünü, diğer kurumlarla karşılaştırıldığında ne durumda olduklarını ve kendilerinden neler beklendiğine dair fikir sahibi olabilirler. Çoğunlukla kurumların kendini değerlendirme sürecinde kamuoyu baz alınıyor gibi görünse de sürece çalışanlar ve kurumun doğrudan etkileşim içinde olduğu tüm taraflar da dahil olmaktadır. Çünkü çalışanlar içinde bulundukları kurumun birer temsilcisi görevini üstlendiği için örgütsel prestijin tasarlanmasında yol gösterici ve yönlendirici bir rol oynar. ${ }^{4}$ Aslında kavram, çalışanların kendisine sorduğu "dışarıdakiler organizasyonla ilişkim hakkında ne düşünüyorlar?" sorusuna da cevap olmaktadır. Örgütsel prestij aynı zamanda bireyin "ben bu örgütte çalıştığım için başkaları benim hakkımda ne düşünür?" düşüncesine dayanmaktadır. $\mathrm{Bu}$ da çalışanın süreç içerisinde elde ettiği düşünceler doğrultusunda örgüt hakkındaki fikirlerini oluşturmaktadır. ${ }^{5,6}$

Örgütsel prestij örgütün davranışlarıyla da yakından ilgilenir. Çünkü çalışan, işveren, müşteri, tedarikçi vb. gibi iç ve dış paydaşlar örgütsel prestiji olumlu olarak algıladıkları takdirde, örgütten elde ettikleri tatmin, bağl11ık, örgütsel özdeşleşme duygusu da o kadar fazla olacaktır. Örgütsel prestiji güçlü olan kurumların aynı zamanda satışları, yatırım firsatları olumlu yönde etkilenmektedir. Bu durumda kurumlar uzun süreli hedeflerini gerçekleştirebilmek, rakipleri karşısında üstünlük kazanabilmek ve toplumda bir yer edinebilmek için güçlü bir örgütsel prestije ihtiyaç duymaktadır. ${ }^{7}$

Örgütsel özdeşleşme kavramı günümüzde insan kaynağının değerini kavrayan örgütler çalışanlarıyla güçlü bir bağ kurma çabası içinde bulunmaktadırlar. $\mathrm{Bu}$ bağlamda örgütsel özdeşleşme, çalışan ve örgüt arasında köprü görevi gören ve kurulması istenen bağın altını çizen bir kavramdır. ${ }^{8,9}$ Yine bu doğrultuda örgütsel özdeşleşme kavramı çalışanın örgütle iş birliği içinde bulunarak, 
örgüte davranış ve tutumlarıyla destek olmasını içermektedir. ${ }^{10}$ Genel olarak örgütsel özdeşleşmenin temeli 3 unsura dayanmaktadir: ${ }^{11}$

-Ana unsur, bireyin örgütle ilgili tüm amaç ve hedefleri kendisininki gibi benimseyerek örgütsel özdeşleşme sürecine dahil olmasıdır.

-Bireyin örgütle ilgili olan her işi kendi isteğiyle ve severek yapmasıdır.

- Bireyin örgütte kalmaya devam etmek için istekli olmasıdır.

Örgütsel prestij ve örgütsel özdeşleşmeyi ele alan çalışmalarda, örgütsel prestij kavramı örgütsel özdeşleşmeyi sağlayan unsurlardan biri olarak görülmektedir. Smidts ve ark. özdeşleşme için iki temel güdünün varlığına ihtiyaç duyulduğundan bahsetmiştir. ${ }^{12}$ Bunlardan ilki benlik sinıflandırma ihtiyacı, diğeri ise benlik geliştirme ihtiyacıdır. İnsanlar prestijli olarak algıladıkları örgütlerle özdeşleşme eğiliminde olacaklardır. Prestijli bir örgütün üyesi olmak, kişinin öz saygısını arttırarak benlik geliştirme ihtiyacını karşılayacaktır. Mael ve Asforth da yaptıkları çalışmada örgütün prestiji arttıkça, özdeşleşme yoluyla öz saygıyı arttırma olanağının artacağını söyleyerek bu durumu desteklemiştir. ${ }^{13}$ Yapılan diğer araştırmalarda örgütsel prestijin özdeşleşme üzerinde etkisi olduğunu ve bireylerin bilişsel olarak genellikle güçlü olanla özdeşleştiğini göstermektedir. Bir bireye, örgüte veya düşünceye yönelik popüler destek, aniden ivme kazanır ve yükselir. $\mathrm{Bu}$ durum örgütlerde sıkça görülen sürü psikolojisini kısmen açıklamaktadır. Olumlu özdeşleşme arzusu, "en küçük çoğunluk belirtisini ezici bir çoğunluğa dönüştüren bir şekilde şampiyon yaratır" şeklinde açıklanmıştır. ${ }^{14}$ Ashforth ve Mael'in söylemleri, örgütsel prestijin yüksek olarak algılanmasının, çalışanların örgütleri ile olan özdeşleşme seviyelerini de $\operatorname{artt1ğ1}$ yönündedir. Örgütün prestij düzeyi konusunda çalışanların değerlendirme isteği içinde olduğu görülmektedir. $\mathrm{Bu}$ istek olumlu bir sonuç doğurduğu sürece, çalışanlar kendilerini örgütle bütün olarak nitelendirilmektedir. ${ }^{15}$ $\mathrm{Bu}$ bağlamda çalışmada örgütsel prestijin örgütsel özdeşleşme üzerinde etkisi olup olmadığı ortaya konmaya çalışılmıştır.

\section{MATERYAL VE METOT}

$\mathrm{Bu}$ araştırma Konya ilindeki çalışma yapılmasına izin veren özel hastanelerde gerçekleştirilmiştir. Araştırma ilişkisel tarama modelinde bir çalışmadır. İlişkisel tarama modeli, iki veya daha çok değişken arasında birlikte değişim varlığını ve/veya derecesini belirlemeyi amaçlayan araştırma modelidir. Tarama yoluyla bulunan ilişkiler gerçek bir neden-sonuç ilişkisi ortaya çıkarmaz ancak bir değişkenin bilinmesi halinde diğerinin kestirilmesi konusunda faydalı ipuçları vermektedir. ${ }^{16}$

\section{Araştırmanın Evren ve Örneklemi}

Araştırma evrenini Konya ilinde faaliyet gösteren özel hastanelerden çalışma yapılmasına izin veren 5 özel hastanenin çalışanları oluşturmaktadır. Araştırma evreninin tümüne ulaşmak zaman ve maliyet açısından zorlu olacağ üzerinden örneklem alınma yoluna gidilmiştir. Hastaneler isimlerin gizli tutulmasını istediği için yapılan bu araştırmada hastanelerin kendi isimlerine yer verilmemekte $A, B, C, D$ ve $E$ hastaneleri şeklinde bahsedilmektedir. Araştırmanın evrenini sirasiyla 111, 233, 143, 98 ve 415 olmak üzere toplam 1000 çalışan oluşturmaktadır. Araştırmanın örnekleminin belirlenmesinde tesadüfü örneklem yöntemi kullanılmıştır ve formüle göre çalışmanın örneklem grubu 278 sağlık çalışanından oluşmalıdır. ${ }^{17}$ Hedeflenen örneklem sayısına ulaşabilmek için 440 anket hastane çalışanlarına elden dağıtılmıştır. Anketlerden 319'u geri dönmüştür ve bunlardan 24 tanesi eksik ya da hatalı doldurulduğu olduğu için elenmiş 295 tanesi araştırmada kullanılabilir bulunmuştur. Ancak doktorlara ait anket sayısı (12) az olduğu için istatistiksel analizlerden çıkartılmak durumunda kalınmış 
ve analizi yapılan toplam anket sayısı 283 olmuştur.

\section{Veri Toplama Aracı}

Araştırmada anket yöntemi kullanılmış olup veriler Kasim 2017-Mart 2018 tarihleri arasında katılımcılardan toplanmıştır. Anket üç bölümden oluşmaktadır. Birinci bölümünde araştırmaya katılanların demografik özelliklerini anlamaya yönelik kişisel bilgi formuna yer verilmiştir. Anketin ikinci ve üçüncü kısmında Örgütsel Prestij Ölçeği ve Örgütsel Özdeşleşme Ölçeği kullanılmıştır. Bu bağlamda, örgütsel prestiji ölçmek üzere Mael tarafindan geliştirilen, Güleryüz tarafından Türkçeye uyarlanarak geçerlilik ve güvenilirlik analizi yapılmış olan Algılanan Örgütsel Prestij Ölçeği kullanılmıştır. Ölçek sekiz maddeden oluşmaktadır. Ölçeğin Cronbach Alpha değeri $0,627^{\prime}$ dir. $^{18}$

Araştırmada ayrıca örgütsel özdeşleşme düzeyini ölçmek için Mael ve Ashforth tarafından geliştirilen 6 maddeden oluşan Örgütsel Özdeşleşme Ölçeği'nin orijinali temel alınarak Eker tarafından tekrar düzenlenen ve geliştirilen 13 soruluk ölçek kullanılmıştır. ${ }^{13,19}$ Öğretim elemanlarının örgütsel özdeşleşmesini ölçmek amacıyla geliştirilen ölçekteki sorular bu çalışmada hastanelere uygun olarak uyarlanmıştır. Ölçeğin Cronbach Alpha değeri 0,917'dir.

\section{Araştırmanın Etik Yönü}

Araştırma için Necmettin Erbakan Üniversitesi Meram Tıp Fakültesi İlaç ve Tıbbi Cihaz Dışı Araştırmalar Etik Kurul
Başkanlığı'ndan 22.09.2017 tarihli izin alınmıştır. Araştırmanın kurumlarda yapılabilmesi için çalışmanın yürütüleceği hastanelerden sözlü ve yazılı izin alınmıştır. Ancak hastaneler isimlerinin belirtilmesini istemediği için yazılı izin belgeleri sunulamamıştır.

\section{Araştırma Verilerinin Analizi}

Araştırmada SPSS 22.0 veri analiz programı kullanılmıştır. Katılımcıların sosyodemografik özellikleri frekans ve yüzde olarak verilmiştir. Verilerin istatistiksel analizinde Pearson korelasyon analizi, tek yönlü varyans analizi, bağımsız iki örneklem $\mathrm{t}$ testi ve regresyon analizinden faydalanılmıştır. Analizlerde sonuçlar \%95'lik güven aralığında, $0,05 \quad(\mathrm{p}<0,05)$ anlamlılık düzeyinde değerlendirilmiştir.

\section{Araştırmanın Kısıtlılıkları}

$\mathrm{Bu}$ araştırma;

-Yalnızca Konya ilinde ve özel hastanelerde yapılmış olmasıyla,

-İzin alınan hastanelerde çalışmaya katılan sağlık çalışanlarıyla,

-Araştırmada kullanılan veri toplama araçlarıyla,

-Verilerin analizinde kullanılan istatistiksel yöntemlerle sinırlıdır.

$\mathrm{Bu}$ sinırliliktan dolayı bulgular ve sonuçlar, yalnızca burada çalışan sağlık çalışanları için geçerlidir. Araştırmanın Türkiye'de bulunan diğer sağlık çalışanlarına genellenebilmesi için daha geniş kapsamlı örneklem üzerinde çalışılması gerekmektedir.

\section{BULGULAR VE TARTIŞMA}

Araştırma kapsamında değerlendirilen çalışanların demografik özelliklerine ilişkin bilgileri aşağıda tabloda verilmiştir.
Tablo 1. Araştırmaya Katılanların Demografik Özelliklerine İlişskin Bulgular

\begin{tabular}{lcc}
\hline Değişken & N & Yüzde \\
\hline Cinsiyet & & \\
\hline Kadın & 215 & 76.0 \\
Erkek & 68 & 24.0 \\
\hline Yaş & & \\
\hline$<30$ & 202 & 71.4 \\
$30+$ & 81 & 28.6 \\
\hline
\end{tabular}




\begin{tabular}{|c|c|c|}
\hline $\begin{array}{l}\text { GÜSBD 2021; 10(3): } 373 \text { - } 382 \\
\text { GUJHS 2021; } 10(3): 373 \text { - } 382\end{array}$ & & $\begin{array}{l}\text { Gümüšshane Üniver } \\
\text { Gümüşhane Univers }\end{array}$ \\
\hline $\begin{array}{l}\text { Tablo } 1 \text { (Devamı). } \\
\text { Demografik Özellikler }\end{array}$ & $\begin{array}{l}\text { Irmay } \\
\text { lişkin }\end{array}$ & $\begin{array}{l}\text { a Katılanların } \\
\text { Bulgular }\end{array}$ \\
\hline Medeni Durum & & \\
\hline Evli & 117 & 41.3 \\
\hline Bekar & 166 & 58.7 \\
\hline Eğitim Durumu & & \\
\hline Lise-Önlisans & 144 & 50.9 \\
\hline Lisans-Lisansüstü & 139 & 49.1 \\
\hline Meslek Grubu* & & \\
\hline Hemşire & 92 & 32.5 \\
\hline Sağlık Teknisyeni & 68 & 24.0 \\
\hline Sağlık Hizmetleri & 15 & 5.3 \\
\hline Genel İdari & 88 & 31.1 \\
\hline Yardımcı & 20 & 7.1 \\
\hline Meslekte Çalışma Yılı & & \\
\hline$<5$ & 177 & 62.5 \\
\hline $5+$ & 106 & 37.5 \\
\hline Kurumda Çalışma Yıl & & \\
\hline$<5$ & 222 & 78.4 \\
\hline $5+$ & 61 & 21.6 \\
\hline Gelir Düzeyi & & \\
\hline 1600 ve alt1 & 164 & 58.0 \\
\hline 1600 üstü & 119 & 42.0 \\
\hline Toplam & 283 & 100 \\
\hline
\end{tabular}

Tablo 1 incelendiğinde 283 çalışanın 215'i kadın, 68'i erkektir. Bu rakamlara göre katılımcıların \%76'sını kadınlar, \%24'ünü erkekler oluşturmaktadır. Araştırmaya katılanların \%71,4'ü (202 kişi) 30 yaş altı grupta, \%28,6's1 (81 kişi) 30 yaş üstü grupta yer almaktadır. Araştırmaya katılanların \%43,4'ünün (128 kişi) medeni durumu evli, \%56,6'sının (167 kişi) ise medeni durumu bekârdır. Araştırmaya katılanların \%50,9'u (144 kişi) lise ve ön lisans mezunu, \%49,1'i (139 kişi) ise lisans ve lisansüstü mezun kişiler oluşturmaktadır. Katılımcıların eğitim durumlarının birbirine yakın olduğu görülmektedir. Araştırmaya katılanların \%32,5'i (92 kişi) Hemşire Grubunda, \%24'ü (68 kişi) Sağlık Teknisyenler Grubunda, \%5,3'ü(15 kişi) Sağlik Hizmetleri Grubunda, \%31,1'i (88 kişi) Genel İdari Hizmetler Grubunda, \%7,1'i (20 kişi) Yardımcı Hizmetler Grubunda yer almaktadir. Katılımcıların çoğunluğu Hemşire Grubunda yer almaktadır. Araştırmaya katılanların \%62,5'i (177 kişi) 5 yıldan az, \%37,5'i (106 kişi) ise 5 yıldan fazla süredir aynı meslekte

çalışmaktadır. Araştırmaya katılanların çoğunluğunun 5 yıldan az süredir çalıştığı görülmektedir. Araştırmaya katılanlardan \% 78,4'ü (222 kişi) 5 yıldan az, \%21,6's1 (61 kişi) ise 5 yıldan fazla süredir aynı kurumda çalışmaktadır. $\mathrm{Bu}$ oranlara bakıldığında çalışanların görev aldıkları hastanelerde genel olarak 5 yıldan az süredir hizmet verdikleri görülmektedir. Araştırmaya katılanların gelir düzeyleri değerlendirildiğinde \%58'i (164 kişi) 1600 TL'nin altında, \%42'i (119 kişi) ise 1600 TL'nin üstünde maaş almaktadır. Katılımcıların gelir durumlarının birbirine yakın olduğu görülmektedir.

\section{Örgütsel Prestij Değerlendirilmesi \\ Ölçeğinin}

Demografik özellikler ile örgütsel prestij ölçeği arasında yapılan $\mathrm{t}$ testi sonuçlarına göre;

-Katılımcilardan erkekler $(\overline{\mathrm{x}}=3,34)$ ile kadinlar $\quad(\overline{\mathrm{x}}=3,41) \quad$ arasında farklılık bulunamamıştır $(\mathrm{p}=0,347)$.

-Katılımcilardan 30 yaş üstü grupta $(\overline{\mathrm{x}}=3,35)$ yer alanlar ile 30 yaş altı grupta $(\overline{\mathrm{x}}=3,35)$ yer alanlar arasinda farklılik bulunamamıştır $(p=0,955)$.

-Lise ve ön lisans $(\overline{\mathrm{x}}=3,37)$ mezunları ile lisans ve lisansüstü grubunda $(\overline{\mathrm{x}}=3,33)$ yer alanlar arasında farklılık bulunamamıştır $(\mathrm{p}=0,549)$.

-Meslekte çalışma süresi 5 yıl altında $(\bar{x}=3,38)$ çalışan katılımcılarla, 5 yıl üstünde çalışanlar $\quad(\bar{x}=3,30)$ arasında farklılık bulunamamıştır $(\mathrm{p}=0,239)$.

-Kurumda çalışma süresi 5 yıl altında $(\overline{\mathrm{x}}=3,36)$ çalışan katılımcılarla, 5 yıl üstünde çalışanlar $\quad(\overline{\mathrm{x}}=3,34)$ arasında farklılık bulunamamıştır $(\mathrm{p}=0,888)$.

•1.600 TL'nin altında $(\bar{x}=3,41)$ çalışan kat1lımc1larla, 1.600 TL'nin üstünde çalışanlar $(\overline{\mathrm{x}}=3,28)$ arasında farklılık bulunamamıştır $(\mathrm{p}=0,066)$.

Meslek grupları ile örgütsel prestij ölçeği arasında yapılan ANOVA testi sonuçları Tablo 2'de gösterilmiştir. 
Tablo 2. Örgütsel Prestij Ölçeği ANOVA Sonuçları

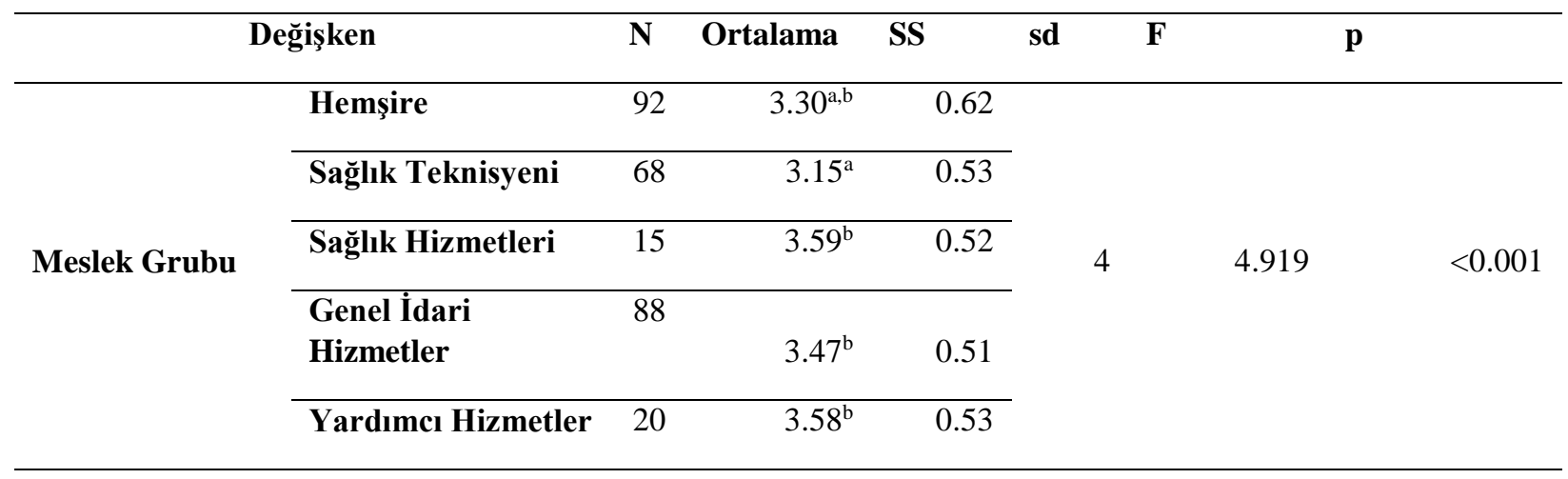

Tablo 2'ye göre hemşire $(\overline{\mathrm{x}}=3,30)$, sağlik teknisyeni $(\overline{\mathrm{x}}=3,15)$, sağlik hizmetleri $(\overline{\mathrm{x}}$ $=3,59)$, genel idari hizmetler $(\overline{\mathrm{x}}=3,47)$ ve yardımc hizmetler $(\overline{\mathrm{x}}=3,58)$ grupları arasında farkl1lık bulunmuş̧ur $(\mathrm{p}<0,001)$. Farklılı̆ 1 hangi grubun ortaya çıkardığı Duncan testi ile belirlenmiștir. Duncan testinde karşılaştırmalarda ortalamaların sıralama farklılıklarına göre, sağlık teknisyenleri a grubunda iken, sağlık hizmetleri, genel idari hizmetler ve yardımc hizmetler $b$ grubunda, hemşireler ise hem $a$ hem $b$ grubunda yer almıştır. Buna göre sağlık teknisyenleri diğer meslek gruplarına göre daha düşük ortalama göstermiştir.

\section{Örgütsel Özdeşleşme Ölçeğinin Değerlendirilmesi}

Demografik özellikler ile örgütsel prestij ölçeği arasında yapılan $t$ testi sonuçlarına göre;

-Kat1limcilardan erkekler $(\bar{x}=3,66)$ ile kadınlar $\quad(\bar{x}=3,52) \quad$ arasinda farklılık bulunamamıştır $(\mathrm{p}=0,194)$.
-Katılımcılardan 30 yaş üstü grupta $(\overline{\mathrm{x}}=3,62)$ yer alanlar ile 30 yaş altı grupta $(\overline{\mathrm{x}}=3,53)$ yer alanlar arasında farkll1lk bulunamamıştır $(\mathrm{p}=0,353)$.

-Lise ve ön lisans $(\overline{\mathrm{x}}=3,57)$ mezunları ile lisans ve lisansüstü grubunda $(\overline{\mathrm{x}}=3,53)$ yer alanlar arasında farklılık bulunamamıştır $(\mathrm{p}=0,660)$.

-Meslekte çalışma süresi 5 yıl altında $(\overline{\mathrm{x}}=3,55)$ çalışan katılımcılarla, 5 y1l üstünde çalışanlar $\quad(\overline{\mathrm{x}}=3,56)$ arasında farkl111k bulunamamışıtır $(\mathrm{p}=0,903)$.

-Kurumda çalışma süresi 5 yıl altında $(\bar{x}=3,55)$ çalışan katılımcılarla, 5 y1l üstünde çalışanlar $\quad(\overline{\mathrm{x}}=3,56)$ arasında farkl1lık bulunamamıştır $(\mathrm{p}=0,218)$.

-1.600 TL'nin altında $(\bar{x}=3,63)$ çalışan katılımcılarla, $\quad 1.600$ TL'nin üstünde çalışanlar $\quad(\overline{\mathrm{x}}=3,45)$ arasında farklılık bulunamamıştır $(\mathrm{p}=0,063)$.

Meslek grubu ile Örgütsel Özdeşleşme ölçeği arasında yapılan tek yönlü ANOVA testi sonucu Tablo 3'de gösterilmiştir.

Tablo 3. Örgütsel Özdeşleşme Ölçeği ANOVA Sonuçları

\begin{tabular}{|c|c|c|c|c|c|c|c|c|c|}
\hline \multicolumn{2}{|r|}{ Değişsen } & \multirow{2}{*}{$\begin{array}{l}\mathbf{N} \\
92\end{array}$} & \multirow{2}{*}{$\begin{array}{l}\text { Ort. } \\
3.49^{\mathrm{a}, \mathrm{b}}\end{array}$} & \multirow{2}{*}{$\begin{array}{ll}\text { SS } & \\
0.93\end{array}$} & \multirow[t]{2}{*}{ sd } & \multirow{2}{*}{\multicolumn{2}{|c|}{$\mathbf{F}$}} & \multicolumn{2}{|c|}{$\mathbf{p}$} \\
\hline \multirow{5}{*}{ Meslek Grubu } & Hemşire & & & & & & & \multirow{5}{*}{3.907} & \multirow{5}{*}{0.004} \\
\hline & Sağlık Teknisyeni & 68 & $3.30^{\mathrm{a}}$ & 0.71 & & \multirow{4}{*}{4} & & & \\
\hline & Sağlık Hizmetleri & 15 & $3.68^{\mathrm{a}, \mathrm{b}}$ & 0.68 & & & & & \\
\hline & Genel İdari Hizmetler & 88 & $3.72^{\mathrm{b}}$ & 0.64 & & & & & \\
\hline & Yardımcı Hizmetler & 20 & $3.87^{\mathrm{b}}$ & 0.89 & & & & & \\
\hline
\end{tabular}


Tablo 3'e göre hemşire $(\bar{x}=3,49)$, sağlık teknisyeni $(\overline{\mathrm{x}}=3,30)$, sağl1k hizmetleri $(\overline{\mathrm{x}}$ $=3,68)$, genel idari hizmetler $(\bar{x}=3,72)$ ve yardımc hizmetler $(\overline{\mathrm{x}}=3,87)$ grupları arasında farklılık bulunmuştur $(p=0,004)$. Farklılığ hangi grubun ortaya çıkardığı Duncan testi ile belirlenmiştir. Duncan testinde karşılaştırmalarda ortalamaların sıralama farklılıklarına göre, sağlık teknisyenleri a grubunda iken, sağlik hizmetleri, genel idari hizmetler ve yardıme hizmetler b grubunda, hemşireler ise hem a hem $b$ grubunda yer almıştır. Buna göre sağlık teknisyenleri diğer meslek gruplarına göre daha düşük ortalama göstermiştir.

\section{Örgütsel Prestijin Örgütsel Özdeşleme Düzeyine Etkisi}

Örgütsel prestijin örgütsel özdeşleşmeye etkisinin belirlenmesi için korelasyon ve regresyon analizleri yapılmıştır. Örgütsel prestij ve örgütsel özdeşleşme arasında yapılan Pearson korelasyon testi sonuçlarına göre, iki ölçek arasında orta düzey $(r=0,679$, $\mathrm{p}<0,001) \quad$ pozitif anlamlı bir ilişki bulunmuştur. Örgütsel prestij ile örgütsel özdeşleşme ölçekleri arasında yapılan doğrusal regresyon analizi parametreleri Tablo 4'de sunulmuştur.

Tablo 4.Örgütsel Prestij ve Örgütsel Özdeşleşme Ölçekleri Arasında Yapılan Regresyon Analizi

\begin{tabular}{lr}
\hline Regresyon Parametreleri & \multicolumn{1}{c}{ Değer } \\
\hline a (eğim) & 0,427 \\
\hline b (regresyon katsayısı) & 0,933 \\
\hline $\mathbf{R}^{\mathbf{2}}$ & 0,452 \\
\hline Kareler Toplamı & 82,71 \\
\hline $\mathbf{F}$ & 241,40 \\
\hline $\mathbf{p}$ & $<0,0001$ \\
\hline
\end{tabular}

Regresyonun eğimi (a) 0,427 ve regresyon katsayısı (b) 0,933 olarak tespit edilmiştir. Bağımsız değişken olan örgütsel prestijin örgütsel özdeşleşme düzeyine etkisinin anlamlı olduğu ve örgütsel prestijin tek başına örgütsel özdeşleşmenin \%45'ini açıkladığ bulunmuştur $\left(\mathrm{R}^{2}=0,452\right)$.
Sağlık çalışanlarının meslek gruplarına göre örgütsel prestij düzeyleri arasında anlamlı bir farklılık tespit edilmiştir. Meslek gruplarına örgütsel prestijin etkisiyle ilgili hem sağlık sektöründe hem de diğer sektörlerde yapılan çalışma sayısı oldukça kısıtlı olduğu için, sonuçların doğrudan karşılaştırılması mümkün olmamıştır.

Şirin tarafından İstanbul'da özel bir sektörde çalışan 232 kişi üzerinde yapılan çalışma sonucunda, araştırmaya katılan çalışanların örgütsel prestij puanlarının ortalamalarının cinsiyet açısından istatistiksel olarak anlamlı bir farklılık bulunmamıştır. Erkek ve kadın çalışanların prestij yorumlarının aynı düzeyde olduğunu belirtmek mümkündür. ${ }^{4}$

Sağlık çalışanlarının yaş değişkenine göre örgütsel prestij düzeyleri arasında anlamlı bir fark bulunamamıştır. Yeşiltaş ve ark.'nın Antalya'da faaliyet gösteren bir adet beş yıldızlı otel işletmesi ve beş adet birinci sınıf tatil köyünde çalışan 227 kişi üzerinde yaptıkları çalışma sonucunda, katılımcıların örgütsel prestij düzeyleri yaşlara göre anlamlı bir farkl1lık göstermemiştir. ${ }^{5}$

Sağlık çalışanlarının meslek gruplarına göre örgütsel özdeşleşme düzeyleri arasında anlamlı bir farklılık tespit edilmiştir. Farklılığ1 oluşturan sağlık teknisyenleri grubunda diğer meslek gruplarına göre örgütsel özdeşleşme düzeyinin daha düşük olmasının nedeni olarak bölüm ve kurumlar arasında sirkülasyonun fazla olması düşünülmektedir. Eker öğretim elemanları üzerinde yaptığı çalışma da benzer sonuçlar ortaya koymuştur. ${ }^{19}$ Öğretim elemanlarının akademik unvan unsuru açısından örgütsel özdeşleşmeleri düzeyleri açısından anlamlı bir farklılaşma gözlenmiştir. Kıdem azaldıkça örgütle özdeşleşme düzeyinin arttığı görülmektedir. O'Brien ve arkadaşlarının sağlık sektöründe, 610 çalışan üzerinde yaptığ 1 çalışma sonucunda kıdemli hemşirelerin örgütle özdeşleşme düzeylerinin yardımcı personele göre daha yüksek olduğu tespit edilmiştir. ${ }^{20}$ Alp'in yaptığı çalışma sonucunda, özdeşleşme algılarında meslek grupları değişkenine bağlı olarak anlamlı bir farklılık olmadığı görülmüştür. ${ }^{21}$ 
Sağlık çalışanlarının cinsiyet değişkenine göre örgütsel özdeşleşme düzeylerinde anlamlı bir fark bulunmamıștır. Karaca tarafindan, Elazı '̆' da bir devlet hastanesinde 189 sağlık çalışanına yapılan çalışma sonucunda örgütsel özdeşleme ölçeğine katılma düzeylerinde, katılımciların cinsiyetleri açısından istatistiksel olarak anlamlı bir farklılık bulunamamıştır. ${ }^{22}$ Alp tarafindan, Elbistan Devlet Hastanesindeki sağlık çalışanlarına uygulanan anket sonuçları sağlık çalışanlarının özdeşleşme algılarının cinsiyete göre anlamlı bir farklılık oluşturmadiğ 1 görülmüştür. ${ }^{21} \mathrm{Bu}$ sonuçların tersini gösteren bir çalışmalar da mevcuttur. Findik tarafından, Konya İ'inde 131 aile hekimi üzerinde yapılan araştırma sonucunda örgütsel özdeşleşme düzeyleri ile cinsiyetleri arasında anlamlı farklılıklar olduğu tespit edilmiştir. $^{23}$ Buna göre erkek aile hekimlerinin örgütleriyle özdeşleşme düzeyleri kadın aile hekimlerine göre daha fazladır.

Sağlık çalışanlarının yaş değişkenine göre örgütsel özdeşleşme düzeyleri arasında anlamlı bir farklilık tespit edilmemiştir. Envergil, Karaca, Alp ve Eker'in yaptığ 1 çalışmalar değerlendirildiğinde örgütsel özdeşleme ölçeğine katılma düzeylerinde, katılımcıların yaşları açısından istatistiksel olarak anlamlı bir fark görülmemiştir. ${ }^{19,21,22,24}$ Kaplan tarafından, Nevşehir ilindeki 4 ve 5 yıldızlı otel işletmelerinde çalışan 268 kişiye uygulanan anket sonucunda örgütsel özdeşleşme ile ilgili olarak yaş değişkeni arasında anlamlı farklılıklar olmadığı tespit edilmiştir. ${ }^{25} \mathrm{Bu}$ sonuçların tersini gösteren çalışmalar da mevcuttur. Olukçu tarafindan, Çorum ilinde ilköğretim okullarında görev yapan 400 öğretmen üzerinde yapılan araştırma sonucunda öğretmenlerin yaşlarına bağlı olarak örgütsel özdeşleşme düzeyleri açısından istatistiksel olarak anlamlı bir fark olduğu görülmektedir. 51 yaş ve üstü öğretmenlerin örgütsel özdeşleşme davranışlarının diğer yaş gruplarındaki ögrretmenlere göre daha yüksek olduğu ortaya çıkmıştır. ${ }^{26}$

Medeni durum açısından sağlik çalışanlarının örgütsel özdeşleşme düzeylerine bakıldığında istatistiksel olarak anlamlı bir fark gözlenmemiştir. Karaca ve Eker tarafindan yapılan çalışma da benzer sonuçlar ortaya koymuştur. ${ }^{19,22}$

Sağlık çalışanlarının eğitim durumuna göre örgütsel özdeşleşme düzeyleri arasında anlamlı bir farklılık tespit edilmemiştir. Enli Kalmaz tarafından, belirlenen 10 üniversitede çalışan 788 akademisyen üzerinde yapılan çalışma sonucunda, eğitim düzeyinin örgütsel özdeşleşme düzeyinde istatistiksel olarak anlamlı bir fark yaratmadığ 1 belirlenmiştir. ${ }^{27}$

Polat, yapılan çalışmaları inceleyerek örgütsel prestij algısının yüksek olmasının çalışanların örgütsel özdeşleşme düzeylerini pozitif şekilde etkilediğini tespit etmiştir. Örgütün prestijinin yüksek olması ve grubun buna olan inancinın olumlu yönde olması durumunda örgüt üyeleri örgütleriyle daha fazla özdeşleşeceklerini söylemek mümkündür. ${ }^{28}$

Carmeli ve ark. tarafindan, İsrail'de faaliyet gösteren 4 firmada görev yapan 161 çalışan üzerinde örgütsel prestijin örgütsel özdeşleşme üzerindeki etkisi incelenmiştir. Araştırma sonucunda örgütsel prestijin örgütsel özdeşleşme ile istatistiksel olarak pozitif ve anlamlı bir ilişkisinin olduğu tespit edilmiştir. Carmeli, çalışmasında örgütün dışarıdan başarılı, güçlü yani prestijli olarak algılanmasının çalışanların örgütle özdeşleşmelerine katkı sağlayacağını böylece daha yüksek iş performansı göstermelerine yol açacağını belirtmiştir. ${ }^{29}$

Riketta (2005) tarafından 96 kişi üzerinde yapılan pek çok değişken ile örgütsel özdeşleşme arasındaki ilişkinin analiz edildiği çalışma sonucunda örgütsel prestij ile örgütsel özdeşleşme arasında istatistiksel olarak anlamlı ve pozitif yönde ilişki olduğu tespit edilmiştir. $^{30}$

Mael ve Ashforth tarafindan yapılan örgütsel özdeşleşmenin öncülleri ve ardıllarının ölçüldüğü çalışmada örgütsel özdeşleşme ve algılanan örgütsel prestij arasında istatistiksel olarak pozitif ve anlamlı bir ilişki tespit edilmiștir. ${ }^{13}$ 


\section{SONUÇ VE ÖNERILER}

Araştırmada, örgütsel prestij ve örgütsel özdeşleşme ölçeklerinin her ikisinin de meslek gruplarına göre anlamlı farklılık gösterdiği tespit edilmiştir. Ölçekler arasında orta düzeyde anlamlı bir ilișki bulunmuș, regresyon analizi sonucuna göre ise örgütsel prestijin tek başına örgütsel özdeşleşmenin $\% 45$ 'ini açıkladığ 1 ortaya konmuştur. Bu bağlamda örgütsel prestijin örgütsel özdeşleşmeyi sağlamak açısından etkili olduğu söylenebilir.
Araştırmanın sonuçları, çalışanın daha iyi firsat ve koșullarda çalıșma imkânı bulmasına rağmen prestiji yüksek olması nedeniyle mevcut olarak çalıştığı kurumda kalmayı tercih etme olasılığının oldukça yüksek olduğunu göstermektedir. Çünkü herkes tarafından prestijli görülen bir örgütte çalışmanın örgütsel bağlılığı ve özdeşleşmeyi arttırdığ1 söylenebilir.

KAYNAKLAR

1. İşçan, Ö.F. (2006). "Dönüştürücü/Etkileşimci Liderlik Algıs1 ve Örgütsel Özdeşleşme İlişkisinde Bireysel Farklılıkların Rolü’. Akdeniz Üniversitesi İktisadi ve İdari Bilimler Fakültesi Dergisi, (11), 160-177.

2. Öcel, H. (2013). “Örgüt Kimliğinin Gücü, Algılanan Örgütsel Prestij ve Kişi-Örgüt Uyumu ile Bağlamsal Performans Arasındaki İlișkiler: Örgütsel Bağlılığın Aracı Rolü”. Türk Psikoloji Dergisi, 28 (71), 37-53.

3. Dutton, J, Dukerich, M. and Harquail, V. (1994). "Organizational Images and Member Identification". Administrative Science Quarterly. 39 (2), 239.

4. Şirin, E. (2018). Örgütsel Prestij Algısı ile Çalıșanların Örgüte Bağlılıkları Arasındaki İlişkide Lider Üye Etkileşiminin Rolü Üzerine Bir Araștırma. Yüksek Lisans Tezi, Marmara Üniversitesi Sosyal Bilimler Enstitüsü, İşletme Anabilim Dalı, İstanbul.

5. Yeşiltaş, M, Türkmen, F. ve Ayaz, N. (2011). "Otel İşletmelerinde Algılanan Örgütsel Prestijin Örgütsel Vatandaşlık Davranışları Üzerindeki Etkileri”. Cumhuriyet Üniversitesi İktisadi ve İdari Bilimler Dergisi, 12 (2), 171189.

6. Carmeli, A and Freund, A. 2002. "The Relationship Between Work and Workplace Attitudes and Perceived External Prestige". Corporate Reputation Review, 5 (1), 5168.

7. Bakan, İ, Erşahan, B. ve Kaya, İ. (2006). "Örgütsel Kimliğin ve Örgütsel Prestijin, Örgütsel Vatandaşlık Üzerindeki Etkisi: Bir Alan Arastırması”. Kahramanmaras Sütçü İmam Üniversitesi İktisadi ve İdari Bilimler Fakültesi Dergisi, 6(1), 69-88.

8. Luthans, F. and Youssef, C.M. (2004). "Human, Social, and Now Positive Psychological Capital Management: Investing in People for Competitive Advantage". Organizational Dynamics, 33 (2), 143-160.

9. Kreiner, G.E. and Ashforth, B.E. (2004). "Evidence Toward An Expanded Model Of Organizational Identification". Journal of Organizational Behaviour, 25, 1-27.

10. Miller, V.D, Allen, M, Casey, M.K. and Johnson, J.R (2000). "Reconsidering the Organizational Identification Questionnaire". Management Communication Quarterly. 13 (4), 626-658.
11. Dutton, J, Dukerich, M. and Harquail, V. (1994). "Organizational Images and Member Identification. Administrative Science Quarterly". Organizational Images and Member Identification, 39 (2), 239.

12. Smidts, A, Pruyn, A.T.H. and Van Riel, C.B.M. (2001). "The Impact of Employee Communication and Perceived External Prestige on Organizational Identification". Academy of Management Journal, 44 (5), 1051-1062.

13. Mael, F, Ashforth, B.E. (1992). "Alumni and Their Alma Mater: A Partial Test of The Reformulated Model of Organizational Identification". Journal of Organizational Behavior, 13 (2), 103.

14. Melikoğlu, M. (2009). The Distınctıve Role Of Prestige, Communication And Trust: Organızational Identification Versus Affectıve Commitment. Yüksek Lisans Tezi, Marmara Üniversitesi Sosyal Bilimler Enstitüsü, İngilizce İsletme Anabilim Dalı, İstanbul.

15. Tüzün Kalemci, İ. ve Çağlar, İ. (2008). "Örgütse Özdeşleşme Kavramı ve İletişim Etkinliği İlişkisi”. Journal of Yasar University. 3 (9), 1011-1027.

16. Karasar, N. (2014). Bilimsel Araştırma Yöntemi. Ankara Nobel Yayıncılık, 27. baskı, Ankara, 80-89.

17. İslamoğlu, A.H. (2009). Sosyal Bilimlerde Araştırma Yöntemleri. İzmit: Beta Basım.171.

18. Mael, F. (1988). "Organizarional identification Constructredefinition and a fieldapplication with organizational alumni. Unpublished doctoral dissertation". Wayne State University.

19. Eker, D. (2014). Öğretim Elemanlarının Örgütsel Sosyal Sermayeleri ve Örgütsel Özdeşleşmeleri Arasındaki İlişki. Yüksek Lisans Tezi. Eskișehir Osmangazi Üniversitesi Eğitim Bilimleri Enstitüsü, Eskişehir.

20. O'Brien, K.E. and Allen, T.D. (2003). "The Relative Importance Of Correlates Of Organizational Citizenship Behavior And Counterproductive Work Behavior Using Multiple Sources of Data". Human Performance. 21, 62-88.

21. Alp, A. (2015). Sağlık Çalışanlarında Örgütsel Özdeşleşme, Örgütsel Vatandaşlık ve Örgütsel Çatışma İletişim Algıları Arasındaki Farklılıklar: (Bir Alan Arastırması). Yüksek Lisans Tezi, Beykent Üniversitesi Sosyal Bilimler Enstitüsü, İsletme Yönetimi Anabilim Dalı, İstanbul. 
22. Karaca, B. (2018). Sağlık Personelinin Sanal Kaytarma Davranışları ile Örgütsel Özdeşleşme Düzeyleri Arasındaki İlişkinin İncelenmesi: Bir Kamu Hastanesi Örneği. Yüksek Lisans Tezi, Munzur Üniversitesi Sosyal Bilimler Enstitüsü, İşletme Anabilim Dalı, Tunceli.

23. Fındık, M. (2011). Algılanan Örgütsel Desteğin, Örgütsel Özdeşleşme ve İşten Ayrılma Niyetine Etkisi Araştırması: Konya Aile Hekimleri Örneği. Yüksek Lisans Tezi, Selçuk Üniversitesi Sosyal Bilimler Enstitüsü, İşletme Anabilim Dalı, Konya.

24. Envergil, D. (2018). Sağlık Çalıșanlarının Psikolojik Sözleşme Algılarının Örgütsel Güven, Örgütsel Özdeşleşme ve Örgütsel Vatandaşlık Davranışı Üzerindeki Etkisi. Yüksek Lisans Tezi, Hacettepe Üniversitesi Sosyal Bilimler Enstitüsü, Sağlık Yönetimi Anabilim Dalı, Ankara.

25. Kaplan, A. (2018). Kurumsal Sosyal Sorumluluk ve Kurumsal İtibar Algılamalarının Örgütsel Özdeşleşme Üzerine Etkisi. Doktora Tezi, Selçuk Üniversitesi Sosyal Bilimler Enstitüsü, Konya.

26. Olukçu, E. (2018). Okul Yöneticilerinin Öğretimsel Liderlik Rolleri ile Öğretmenlerin Örgütsel Özdeşleşme Düzeylerinin İlișkisi (Corum İli Örneği). Yüksek Lisans Tezi, Amasya Üniversitesi Sosyal Bilimler Enstitüsü, Temel Eğitim Anabilim Dalı, Amasya.

27. Kalmaz Enli, P. (2018). Örgütsel Güvenin Örgütsel Özdeşleşme ve Mesleki Özdeşleşme Üzerine Etkileri Hakkında Bir Araștırma. Doktora Tezi, Pamukkale Üniversitesi Sosyal Bilimler Enstitüsü, Denizli.

28. Polat, S. (2009). "Organizational Citizenship Behavior (OCB) Display Levels of The Teachers At Secondary Schools According To The Perceptions Of The School Administrators". Procedia Socialand Behavioral Sciences. $1,1591-1596$.

29. Carmeli, A, Gilat, G. and Waldman, D. (2007). "The Role of Perceived Organizational Performance in Organizational Identification, Adjustmentand Job Performance". Journal of Management Studies. 44 (6), 972-992.

30. Riketta, M. (2005). "Organizational Identification: A MetaAnalysis". Journal of Vocational Behavior, 66, 358-384. 